\title{
Aerosol measurements at a high-elevation site: composition, size, and cloud condensation nuclei activity
}

\author{
B. Friedman ${ }^{1}$, A. Zelenyuk ${ }^{2}$, J. Beranek ${ }^{2}$, G. Kulkarni ${ }^{2}$, M. Pekour ${ }^{2}$, A. Gannet Hallar ${ }^{3}$, I. B. McCubbin ${ }^{3}$, J. \\ A. Thornton ${ }^{1}$, and D. J Cziczo ${ }^{4}$ \\ ${ }^{1}$ Department of Atmospheric Sciences, University of Washington, Seattle, WA, USA \\ ${ }^{2}$ Pacific Northwest National Laboratory, Richland, WA, USA \\ ${ }^{3}$ Storm Peak Laboratory, Desert Research Institute, Steamboat Springs, CO, USA \\ ${ }^{4}$ Earth, Atmospheric, and Planetary Sciences Department, Massachusetts Institute of Technology, Cambridge, MA, USA
}

Correspondence to: B. Friedman (bfriedma@uw.edu)

Received: 17 June 2013 - Published in Atmos. Chem. Phys. Discuss.: 9 July 2013

Revised: 29 October 2013 - Accepted: 1 November 2013 - Published: 9 December 2013

\begin{abstract}
Measurements of cloud condensation nuclei (CCN) concentrations, single particle composition and size distributions at a high-elevation research site from March 2011 are presented.

The temporal evolution of detailed single particle composition is compared with changes in $\mathrm{CCN}$ activation on four days, two of which include new particle formation and growth events. Sulfate-containing particles dominated the single particle composition by number; biomass burning particles, sea salt particles, and particles containing organic components were also present. CCN activation largely followed the behavior of the sulfate-containing particle types; biomass burning particle types also likely contained hygroscopic material that impacted $\mathrm{CCN}$ activation. Newly formed particles also may contribute to $\mathrm{CCN}$ activation at higher supersaturation conditions. Derived aerosol hygroscopicity parameters from the size distribution and CCN concentration measurements are within the range of previous reports of remote continental kappa values.
\end{abstract}

\section{Introduction}

Aerosol particles in the atmosphere impact climate through directly absorbing and scattering radiation and indirectly by impacting and altering cloud properties. The latter, termed the "indirect aerosol effect", occurs due to aerosol acting as cloud condensation nuclei (CCN) and ice nuclei, and thus influencing cloud albedo, lifetime, as well as other cloud prop- erties (Albrecht, 1989; Twomey, 1977). The aerosol indirect effect represents the most uncertain components in future climate scenarios (Forster et al., 2007).

A challenge in quantifying aerosol indirect effect is assessing both the spatial and temporal variation of $\mathrm{CCN}$. Whether an aerosol acts as a $\mathrm{CCN}$ and activates to form cloud droplets is determined by both its size and chemical composition (Dusek et al., 2006; Köhler, 1936; McFiggans et al., 2006). The CCN activity of aerosol comprised of organic and inorganic components can be predicted based on the Köhler theory, which states that for each dry particle size of known molecular weight, mass, density, and activity coefficient there exists a critical supersaturation at which any increase in the droplet size will lead to spontaneous growth into a cloud droplet. Laboratory studies have successfully predicted CCN activation of single component aerosol particles (Petters and Kreidenweis, 2007; Raymond and Pandis, 2002, 2003) and multi-component aerosols with simplified mixing states (Abbatt et al., 2005; Bilde and Svenningsson, 2004; Broekhuizen et al., 2004; Kumar et al., 2003; Raymond and Pandis, 2002, 2003).

However, given that ambient aerosol particles are composed of complex mixtures of inorganic and organic components (Murphy et al., 2006), which are relatively unknown in terms of aggregate properties such as solubility, polarity, surface tension, etc., considerable difficulty arises when attempting to link particle source types with aerosol physiochemical properties and their radiative impact (e.g., hygroscopicity, or water uptake, and CCN activation). Further, 
while the aerosol size is crucial in characterizing $\mathrm{CCN}$ activity (Dusek et al., 2006), additional challenges stem from the fact that the aerosol size and chemical composition are constantly evolving in time and space due to atmospheric processing (e.g., oxidation, condensation of trace gases, and heterogeneous chemistry) and variation in aerosol sources and aerosol transport, meaning that the $\mathrm{CCN}$ activity of aerosols is also constantly evolving (Cubison et al., 2008; Furutani et al., 2008; Wang et al., 2008; Wong et al., 2011). These characteristics present a challenge in extending laboratory measurements of $\mathrm{CCN}$ to atmospheric conditions and underline the importance of, and need for, field studies in a variety of conditions and environments to assess our understanding of atmospheric $\mathrm{CCN}$ and associated activation properties (AsaAwuku et al., 2011, Chang et al., 2007; Ervens et al., 2010; Juranyi et al., 2010; Kammermann et al., 2010; Lance et al., 2009; Martin et al., 2011; Moore et al., 2011, 2012; Roberts et al., 2010).

Simplifications of the complex composition of ambient aerosol are sought for modeling purposes and applications in understanding the magnitude of the aerosol indirect effect and the extent of detail necessary in describing aerosol composition. Models may assume internal or external mixing states, which may not accurately define the actual aerosol mixing state, especially as aerosol composition is often size dependent and not static in the atmosphere (Zaveri et al., 2012). Simplifying the aerosol mixing state may lead to reasonable CCN predictions at a specific time or set of environmental conditions, but more information is necessary regarding composition evolution at high time resolution and a variety of locations to determine if predictions are globally accurate.

To address this challenge, in this study we examine changing aerosol mixing state and $\mathrm{CCN}$ activity on a fast timescale at a high-elevation site. Single particle instrumentation allows the in situ determination of the chemical composition of individual particles as a function of size on a particle by particle basis, thus giving information about particle mixing state (Zelenyuk et al., 2009, 2010). Herein, we present measurements of CCN activity, single particle composition, size distributions, and density measured in March 2011 at a high-altitude research site exposed to local boundary layer and free-troposphere conditions, as well as new particle formation (NPF) events. CCN activity measured by the $\mathrm{CCN}$ counter is compared to the single particle chemical composition as a function of supersaturation, as well as aerosol source region.

\section{Methods}

\subsection{Measurement site}

Measurements of the physiochemical properties of atmospheric particles and CCN concentrations were conducted in
March 2011 at the Storm Peak Laboratory (SPL) in northwestern Colorado. Located near Steamboat Springs, CO $\left(40.455^{\circ},-106.744^{\circ} ; 3210 \mathrm{~m}\right.$ a.s.l.), SPL provides a unique high-elevation location to study ambient particles with influences from both the free troposphere, particularly at night, and local sources, particularly during the day when upslope winds provide influence from the local boundary layer (Baustian et al., 2012; Borys and Wetzel, 1997; Hallar et al., 2011; Lowenthal et al., 2002; Richardson et al., 2007). The measurement site also allows study of CCN activation from new particle formation (NPF) events that are frequently observed at SPL (Hallar et al., 2011).

The Storm Peak Laboratory Validation Experiment (StormVEx), conducted from October 2010 to April 2011 and funded by the Department of Energy Atmospheric Radiation Measurement (ARM) Program, deployed an extensive suite of ground-based remote sensors to retrieve cloud properties and in situ aerosol and cloud measurements for validation. Combining SPL observations with concurrent measurements from the second ARM Mobile Facility (AMF2) created a large data set of remote sensing observations and direct in situ measurements (Mastrosov et al., 2012). During StormVEx, instrumentation was deployed at four primary ground sites; measurements presented herein utilize data from the SPL site only.

\subsection{Instrumentation}

Air was sampled through a cyclone impactor providing a size cut of 1.5 micrometers prior to sampling the aerosol size distribution, number concentrations, size and composition of individual particles, and CCN activity of polydisperse ambient aerosol particles. Particle size distributions were measured by a Scanning Mobility Particle Sizer (SMPS) consisting of a DMA (DMA, TSI 3936) and a Condensation Particle Counter (CPC, TSI 3786). The SMPS was calibrated for the ambient pressure at the high altitude and was set to scan from $20 \mathrm{~nm}$ to $800 \mathrm{~nm}$. CCN activation was measured by a Cloud Condensation Nuclei Counter (Droplet Measurement Technologies, CCNC). SPLAT II, a second generation single particle mass spectrometer, measured aerosol asphericity and density, in addition to individual particle compositions and sizes. A schematic of the ambient sampling setup is shown in Fig. 1. Temperature, relative humidity, pressure, and associated meteorology conditions were also continuously monitored throughout the campaign. Individual instruments are described below.

\subsection{CCNC}

The commercial Droplet Measurement Technologies (DMT; Boulder, CO) Cloud Condensation Nuclei Counter (CCNC) is a continuous flow streamwise thermal gradient open cylinder CCN counter described in detail in previous literature (Lance et al., 2006; Roberts and Nenes, 2005). Briefly, flow 


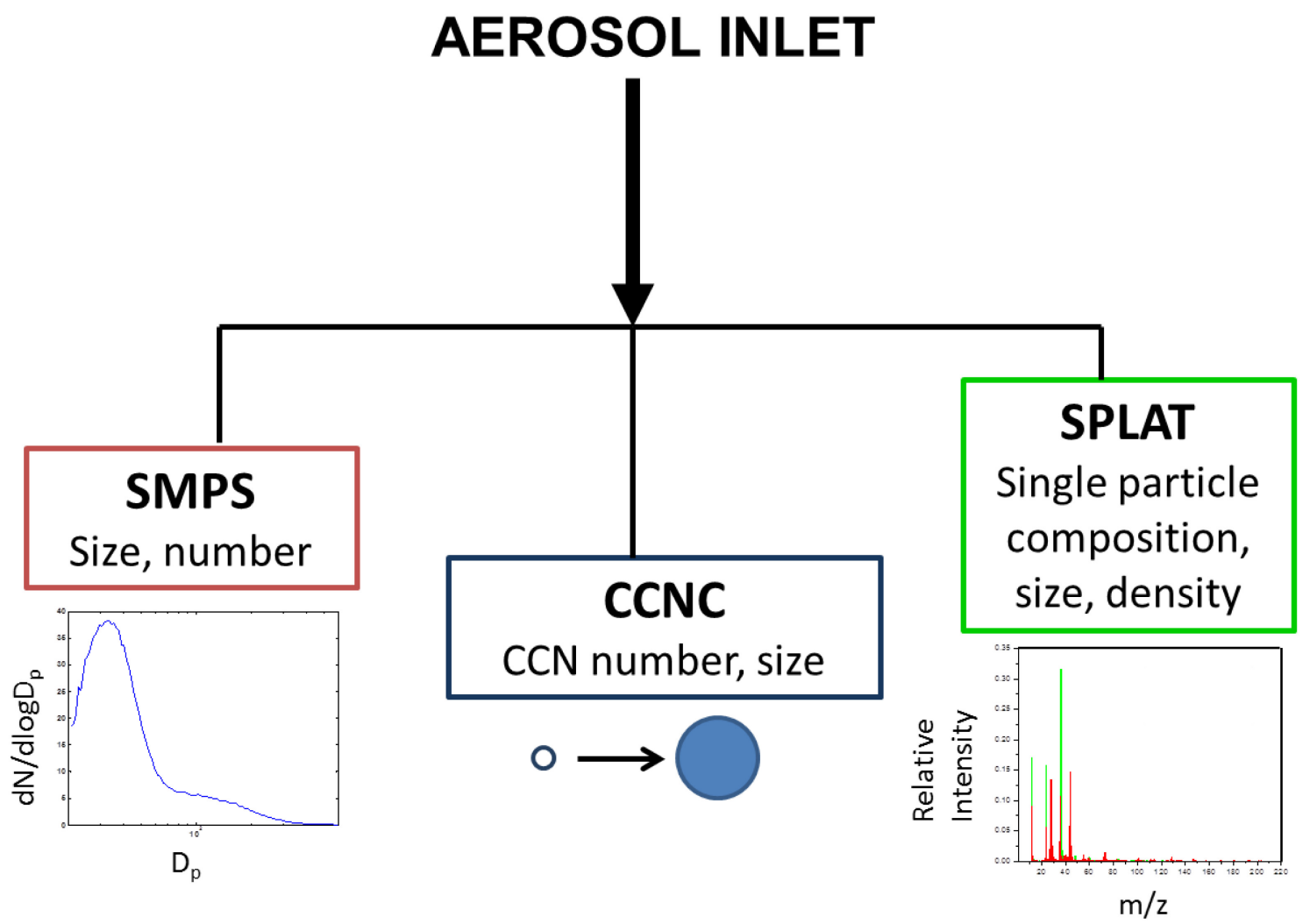

Fig. 1. Schematic of experimental setup used at SPL. Aerosol size and number concentrations were measured by a scanning mobility particle sizer (SMPS), droplet activation and resulting droplet number concentrations as a function of chamber supersaturation were assessed by a Cloud Condensation Nuclei Counter (CCNC), and single particle mass spectrometer (SPLAT II) measured the composition, size, and density of individual particles.

into the CCNC is split into an aerosol and sheath flow; the sheath flow is filtered, humidified, heated, and acts to limit the primary aerosol flow to the center of the CCNC. A positive temperature gradient is then applied to the continuously wetted column in the direction of the flow. Due to the difference in diffusion rates between water and heat, supersaturation with respect to water vapor is generated along the center of the column. Particles will activate and grow into droplets when the supersaturation in the column is equal to the critical supersaturation for the given particle. The critical diameter $\left(D_{\text {crit }}\right)$ is defined as the size at which $50 \%$ of the particles activate into droplets. Droplets growing to sizes greater than 0.75 micrometers are then detected by an internal optical particle counter. The CCNC was calibrated with size-selected ammonium sulfate particles generated by atomizing a $0.1 \mathrm{M}$ aqueous solution of ammonium sulfate; the CCNC was programmed to step through five different supersaturations during the campaign varying from $0.07 \%$ to $0.72 \%$. Data collection at each supersaturation lasted 10 minutes, with the first 3 min discarded to establish equilibrium at the given supersaturation.

\subsection{SPLAT II}

The single particle mass spectrometer SPLAT II is described in detail elsewhere (Zelenyuk et al., 2009). In brief, SPLAT II uses an aerodynamic lens inlet to form a low divergence particle beam and transport the particles into the vacuum system with high efficiency (Zelenyuk et al., 2009). The aerodynamic lens imparts each particle with a velocity that is a narrow function of the particle's vacuum aerodynamic diameter $\left(d_{\mathrm{va}}\right)$. To measure individual particle size and composition each particle is detected by light scattering at two optical detection stages, separated by $10.4 \mathrm{~cm}$, and particle time of flight (PTOF) between the two stages is used to determine particle velocity, and thus its $d_{\mathrm{va}}$. A particle detection event and its PTOF are used to generate size-dependent triggers that fire the $\mathrm{CO}_{2}$ laser, which is used to evaporate semi-volatile components in the particle, and the excimer laser, which ionizes the evaporated plume and ablates the non-volatile particle fraction. Individual particle mass spectra are acquired using an angular reflectron time-of-flight mass spectrometer (TOF-MS) and digitized by a 14 bit A/D converter. 


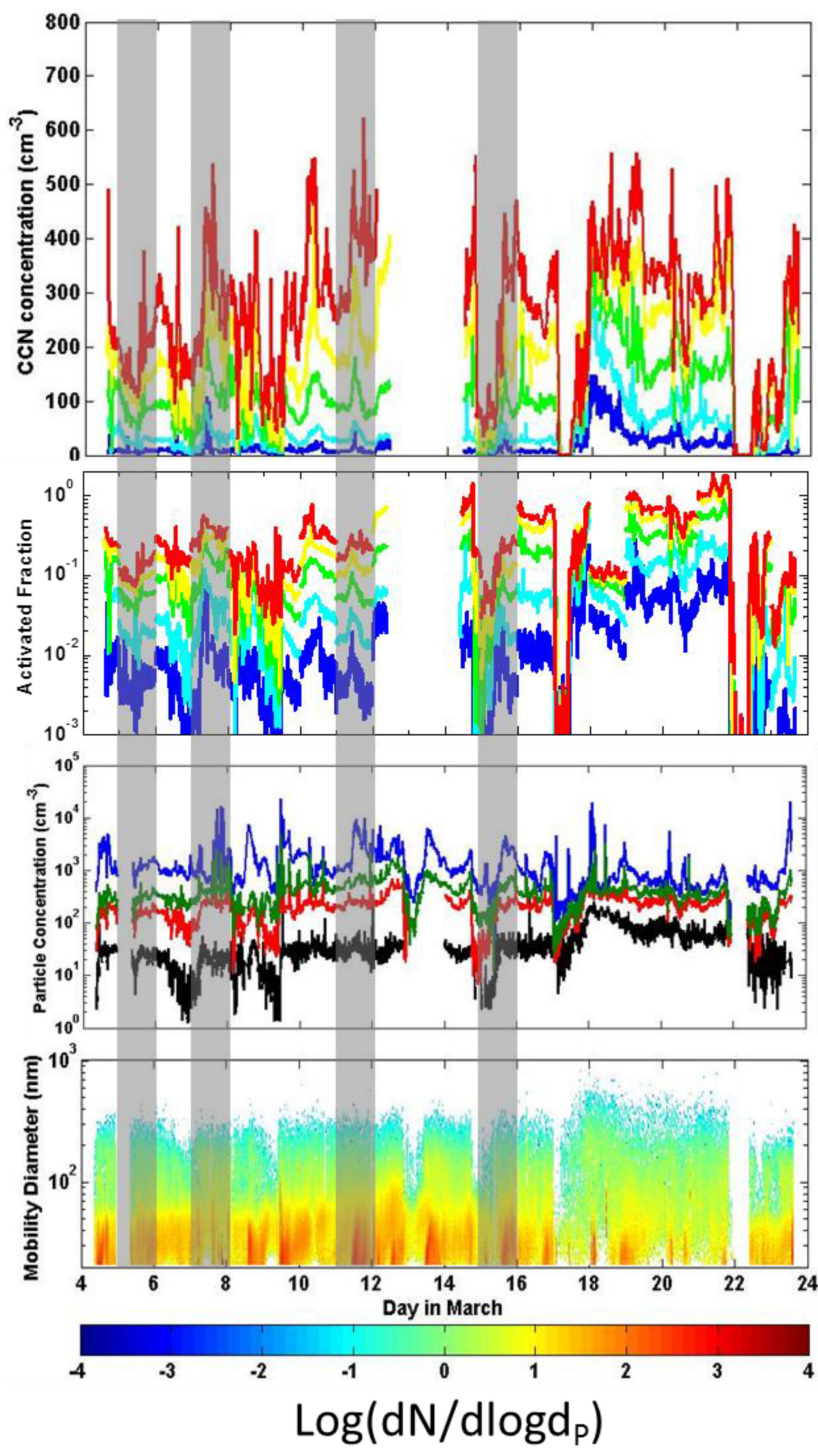

Fig. 2. Aerosol properties measured during March 2011 at Storm Peak Laboratory (SPL). (a) CCN concentrations as a function of supersaturation in the CCNC. Colors correspond to CCNC supersaturations: $0.07 \%$ (blue); $0.12 \%$ (cyan); $0.22 \%$ (green); $0.42 \%$ (yellow); $0.72 \%$ (red). (b) Activated fraction of $\mathrm{CCN}$; colors are the same as (a). (c) Total particle concentrations as a function of aerosol size (blue: all particles $>20 \mathrm{~nm}$; green: particles $>50 \mathrm{~nm}$; red: particles $>80 \mathrm{~nm}$; black: particles $>200 \mathrm{~nm}$ ). (d) Number size distributions (colorbar is $d N / d \log \mathrm{D}_{p}$ ). Grey shaded regions indicate days of detailed analysis presented.

During most of the campaign SPLAT II measured the size, number concentration, asphericity, and composition of individual particles in the size range of $50 \mathrm{~nm}$ to 3 micrometers (Vaden et al., 2011b; Zelenyuk et al., 2009). Particle number concentrations are determined by SPLAT II with one second time resolution based on the measured particle detection rate in the first optical detection stage (Vaden et al., 2011b). Particle asphericity is measured with one second temporal reso- lution by calculating the ratio of the particle detection rates in the two optical detection stages (Vaden et al., 2011b). This ratio is sensitive to particle beam divergence, which is affected by particle size and shape. For spherical particles, the ratio is between 1 and 1.1, and for aspherical particles it increases to $2-4$, depending on particle shape (Vaden et al., 2011b).

Particle $d_{\mathrm{va}}$ size distributions are calculated from the measured PTOF with a temporal resolution on the order of about $60 \mathrm{~s}$, depending on the particle concentrations and the breadth of the size distributions (Vaden et al., 2011b). Periodically, SPLAT II was used to characterize the size and compositions of DMA-classified particles, from which particle effective densities are calculated (Zelenyuk et al., 2009). Particle $d_{\mathrm{va}}$ distributions are also used to calculate particle density based on the instrument characteristic drop-off detection efficiency for small particles (Vaden et al., 2011a). This approach is useful when applied to the size distributions of composition-resolved particles, which are obtained after the mass-spectral data are classified (Vaden et al., 2011a; Zelenyuk et al., 2010). These densities together with the mass spectra are used to obtain quantitative information on particle composition and determine relative compositions in internally mixed aerosol particles (Vaden et al., 2011a; Zelenyuk et al., 2010).

The mass spectra of individual particles characterized during this field campaign were grouped into a number of distinct particle classes using SpectraMiner (Zelenyuk et al., 2006). Classes represent particles with different mixing states, e.g., particles composed of mixtures of organics and sulfate with different relative fractions, sea salt particles, biomass burning particles, etc.), from which the relative number of particles as a function of time were related to the CCN activity. Particle types determined for this study are described in Table 1.

\section{Results}

\subsection{Campaign overview}

$\mathrm{CCN}$ concentrations as a function of supersaturation, the activated fraction of aerosol (the ratio of $\mathrm{CCN}$ to total aerosol concentrations), aerosol concentrations, and size distribution measurements for the duration of the campaign are shown in Fig. 2. Aerosol number concentrations were dominated by particles smaller than $80 \mathrm{~nm}$; NPF events often contributed to the small particle concentration. During measurable precipitation total particle concentrations dropped significantly, as evidenced on 9, 14, 17, and 22 March. CCN concentrations follow the overall aerosol particle concentrations, with higher variability at higher supersaturations due to the variability in the total aerosol concentration and as smaller particles are able to activate. The activated fraction also exhibits variability, ranging from 0.001 to 1 , depending on the 
a
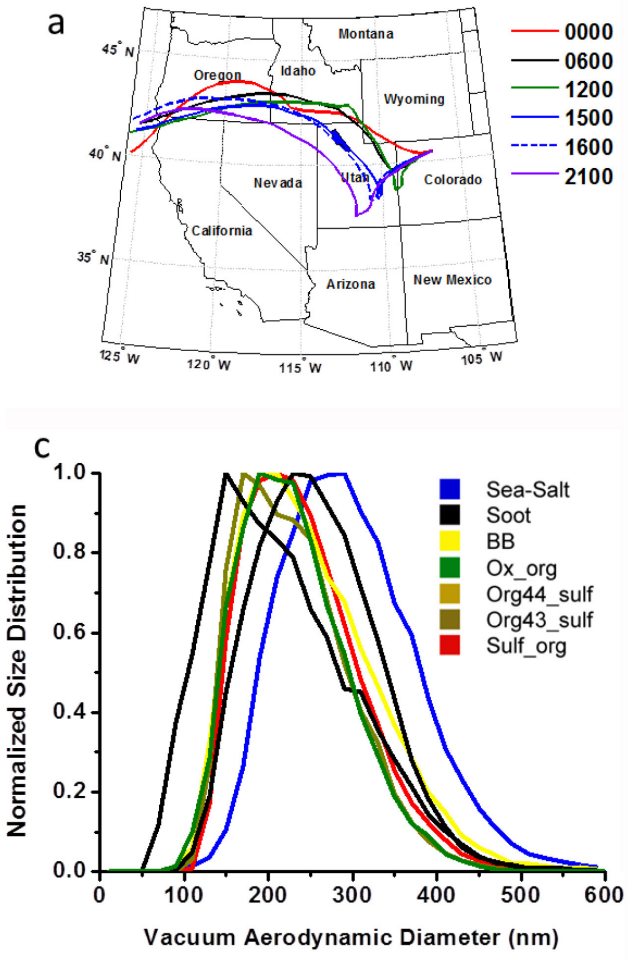
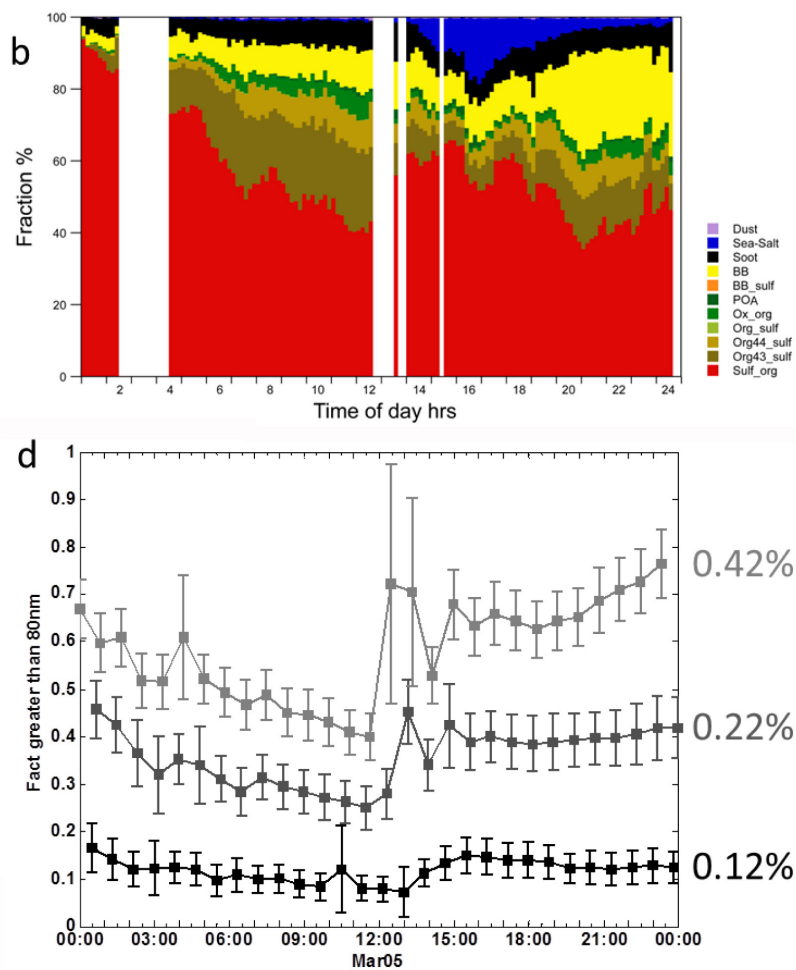

Fig. 3. Calculated back trajectories, aerosol compositions, size distributions, and activated fraction of particles greater than $80 \mathrm{~nm}$ for $5 \mathrm{March}$ 2011. (a) back trajectories at a variety of times throughout the day on 5 March, showing transport of sea salt particles over Salt Lake. (b) time evolution of composition throughout the day, as measured by SPLAT. (c) Composition-resolved size distributions. Colors are the same as the composition plot (b). (d) Activated fraction of particles greater than $80 \mathrm{~nm}$ as a function of measured CCN supersaturation and time of day on 5 March.

supersaturation and ambient aerosol concentrations. Areas highlighted in grey indicate days of focus for detailed analysis, in which CCN activity, presented below, was compared to changes in the single particle compositions,.

\subsection{Case study: sulfate, organics, sea salt, biomass burning periods}

Air masses from the southwest were sampled on 5 March, as indicated by back trajectories (Fig. 3a). Back trajectories also show the air mass passing over Salt Lake City (population 190000) in the afternoon. Total aerosol concentrations ranged from 400 to $2000 \mathrm{~cm}^{-3}$, with lower concentrations in the morning and the highest particle concentrations in the later evening. $\mathrm{CCN}$ concentrations ranged from 1 to $470 \mathrm{~cm}^{-3}$, depending on the supersaturation set in the CCNC and the number of ambient particles. The temporal evolution of particle compositions is shown in Fig. 3b.

SPLAT II measured and sized 4.6 million particles on 5 March, with a mean vacuum aerodynamic diameter of $178 \mathrm{~nm}$. With an average density of $1.48 \mathrm{~g} \mathrm{~cm}^{-3}$ this translates to a mean diameter of about $120 \mathrm{~nm}$. The particles were categorized, according to their mass spectra, into different particle classes (types) listed in Table 1 . On a number ba- sis, particles composed of sulfate mixed with a small amount of organics dominated the entire day, comprising $63 \%$ of the measured particles. The soot particles mixed with small amounts of sulfate were also present throughout the day, comprising $7 \%$ of the total number of particles. Different types of particles composed of organics and sulfate were identified; the two most prevalent were labeled Org43_sulf and Org44_sulf to indicate the dominant organic mass spectral peak. The class labeled Ox_orgs indicates highly oxygenated organics. Primary organic aerosol (POA), indicated by the presence of unsaturated hydrocarbons and high spectral intensities at $m / z 41,43,55,57$ and 69, was the organic class with the least number of particles. Overall, organic-type particles comprised $23 \%$ of the total number of particles. Biomass particles, composed mainly of organics and small amount of sulfates were also observed. Sea salt particles were partially processed (aged) and exhibited variability throughout the day. In the afternoon, when the air mass that passed over Salt Lake City reached the sampling site, sea salt particles comprised $20 \%$ of the total number of particles. Particles composed of sulfate with small amounts of organics dominated in the morning, organic particle types increased throughout the day, and biomass burning particles (indicated by a dominant potassium mass spectral peak) increased at 

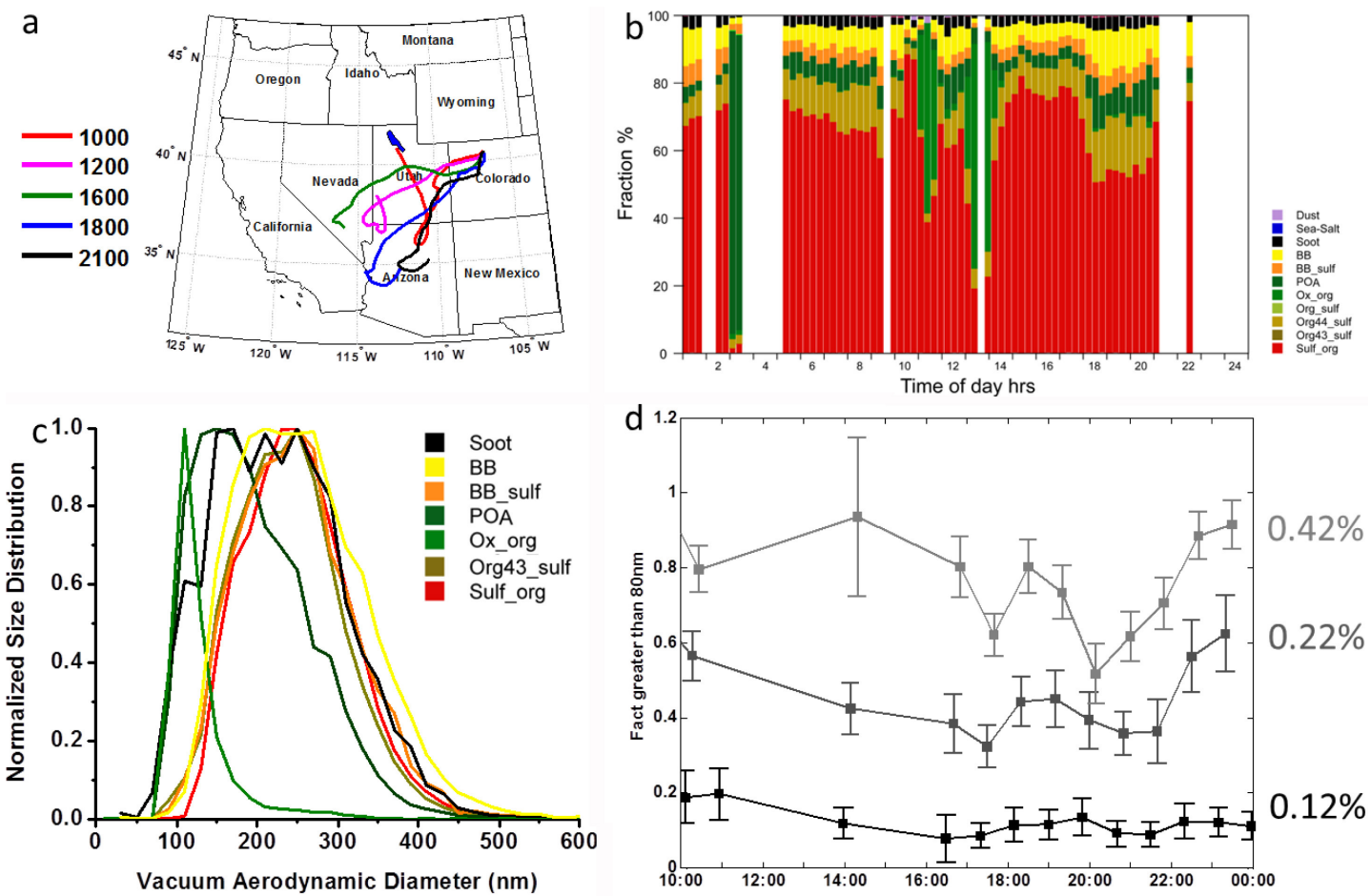

Fig. 4. (a) back trajectories at a variety of times throughout the day on 7 March. (b) time evolution of composition throughout the day, as measured by SPLAT. (c) Composition-resolved size distributions. Colors are the same as the composition plot (b). (d) Activated fraction of particles greater than $80 \mathrm{~nm}$ as a function of measured CCN supersaturation and time of day on 5 March.

Table 1. Particle types determined by SPLAT.

\begin{tabular}{|c|c|}
\hline Particle type/class & Description \\
\hline Sulf_org & $\begin{array}{l}\text { Mixed sulfate/organic particles, composition dominated by } \\
\text { sulfate }\end{array}$ \\
\hline Org43_sulf & $\begin{array}{l}\text { Mixed organic/sulfate particles, composition dominated by } \\
\text { organics with dominant mass spectral peak at } m / z=43\end{array}$ \\
\hline Org44_sulf & $\begin{array}{l}\text { Mixed organic/sulfate particles, composition dominated by } \\
\text { organics with dominant mass spectral peak at } m / z=44\end{array}$ \\
\hline Org_sulf & $\begin{array}{l}\text { Mixed organic/sulfate particles, composition dominated by } \\
\text { organics }\end{array}$ \\
\hline Ox_org & Oxygenated organic particles \\
\hline POA & $\begin{array}{l}\text { Primary organic aerosol (hydrophobic), dominated by } \\
\text { unsaturated hydrocarbons }\end{array}$ \\
\hline BB_sulf & Biomass burning particles mixed with sulfate \\
\hline BB & Biomass burning particles \\
\hline Soot & Soot particles (aged, mixed with sulfate and organics) \\
\hline Sea-Salt & Sea-salt particles (aged) \\
\hline Dust & Dust particles \\
\hline
\end{tabular}

the end of the day, likely due to residential heating from local sources. Cluster analysis also allows determination of composition-resolved size distributions for the day, which are important when considering $\mathrm{CCN}$ activation. Sea salt particles were the largest (peak $d_{\mathrm{va}} 290 \mathrm{~nm}$ ), aged soot particles (soot mixed with sulfate and organics) exhibited a broad distribution (peak $d_{\mathrm{va}} 150 \mathrm{~nm}$ ) indicating different amount of sulfates, and the organics, sulfate, and biomass burning type particles had similar size distributions (peak $d_{\mathrm{va}} 190 \mathrm{~nm}$, $210 \mathrm{~nm}$, and $210 \mathrm{~nm}$, respectively, Fig. 3c).

To focus on particles' CCN activity and comparison to the compositions measured by SPLAT II, the activated fraction of particles larger than $80 \mathrm{~nm}$ was calculated as the ratio of measured $\mathrm{CCN}$, at given instrument supersaturation, to the total number of particles greater than $80 \mathrm{~nm}$ as measured by the SMPS. The lower limit of $80 \mathrm{~nm}$ was chosen to best compare the CCN activity to the measured SPLAT composition and focus on the most atmospherically relevant data. These calculated fractions for three supersaturations are shown in Fig. 3d, with error bars representing the standard deviation. In comparing Fig. 3b-d, we observe that the $\mathrm{CCN}$ activity qualitatively mirrors the behavior of the sulfate-dominated particle type most strongly at supersaturations of $0.22 \%$ and $0.42 \%$. As the fraction of sulfate-dominated particle type increases, $\mathrm{CCN}$ activation also increases; as the fraction of sulfate-dominated particle type decreases and the fraction of 


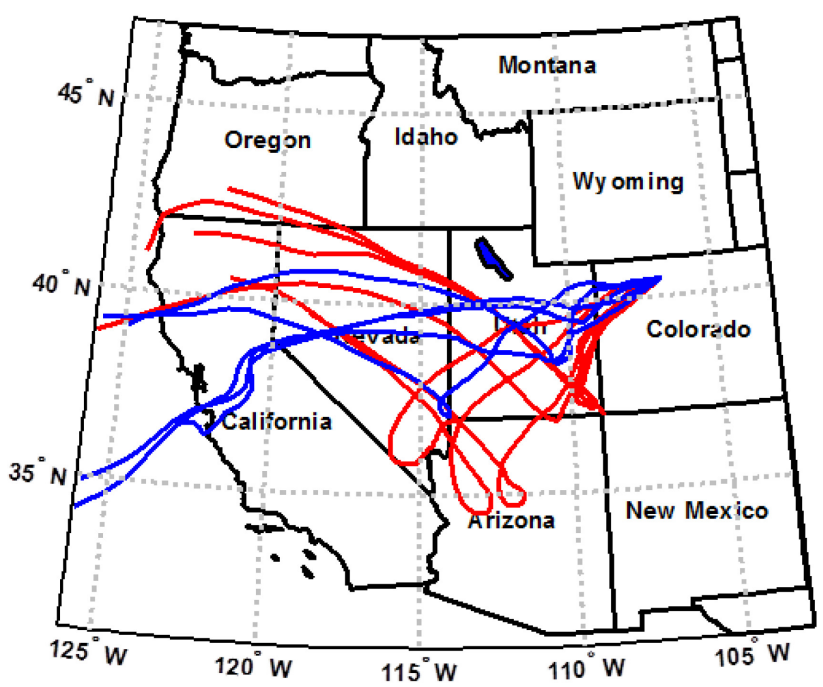

Fig. 5. Back trajectories for 11 March (blue) and 15 March (red).

organic-dominated particle types increases, $\mathrm{CCN}$ activation decreases. CCN activity also increases with the arrival of hygroscopic sea salt particles to the site. Further, that the activated fraction at the end of the day does not decrease is consistent with the observations that biomass burning particles contain some sulfates and are slightly hygroscopic.

\subsection{Case study: sulfate-dominated}

Back trajectories show that air masses from the west and southwest were characterized at SPL on 7 March (Fig. 4a). Similar to 5 March, total particle concentrations ranged from about 50 to $2500 \mathrm{~cm}^{-3}$, with the lowest concentrations observed in the morning. Particle concentrations were fairly consistent in the afternoon, aside from a sharp increase around 18:00 LT, coinciding with an increase in oxygenated organic particles. $\mathrm{CCN}$ concentrations ranged from $1-500 \mathrm{~cm}^{-3}$, with the most variability in the higher supersaturations.

Figure $4 \mathrm{~b}$ shows the temporal evolution of compositions of approximately 102000 particles characterized by SPLAT II throughout the day. Sulfate with a small amount of organics was the dominant particle class, comprising $63 \%$ of the total number of measured particles. The second most common particles were composed of organics mixed with some sulfate. Oxygenated organics (5\%), POA $(8 \%)$, and biomass burning $(10 \%)$ particle types also contributed to the total aerosol composition. While the sulfate-rich particles class was dominant throughout the day, organic particles demonstrated variability, as shown by an increase in POA-type particles in the late morning and oxygenated organic particles in the late afternoon, consistent with an increase in particle number concentrations. Biomass burning particles with and without sulfate were present throughout the day, representing a small fraction of particles. The composition-resolved size distributions show that the organic particle types are the smallest (peak $d_{\mathrm{va}} 110 \mathrm{~nm}$ ), the aged soot particles mixed with some sulfate also exhibit a broad distribution (peak $d_{\mathrm{va}}$ $170 \mathrm{~nm}$ ), while sulfate-dominated and the biomass burning particle types are similar in size (peak $d_{\mathrm{va}} 250 \mathrm{~nm}, 210 \mathrm{~nm}$, and $250 \mathrm{~nm}$, respectively). Density measurements of DMAclassified $100 \mathrm{~nm}$ particles exhibit a range of $1.2 \mathrm{~g} \mathrm{~cm}^{-3}$ to $1.7 \mathrm{~g} \mathrm{~cm}^{-3}$, with a peak density of $1.5-1.6 \mathrm{~g} \mathrm{~cm}^{-3}$, which is consistent with the findings that they were largely composed of mixtures of sulfate and organic components, whose densities are $1.8 \mathrm{~g} \mathrm{~cm}^{-3}$ and $1.2 \mathrm{~g} \mathrm{~cm}^{-3}$, respectively (Vaden et al., 2011a).

The activated fraction of particles greater than $80 \mathrm{~nm}$ follows the same pattern as the sulfate cluster (Fig. 4d), especially at the higher supersaturations. The activated fraction also decreases in the afternoon when the oxygenated organics cluster is peaking, and sulfate is at its minimum. This decrease may be due both to the decrease in the hygroscopic sulfate particle types and the increase in the smaller oxygenated organic particles, suggesting the importance of a particle mixing state.

\subsection{Case study: days with NPF events}

New particle formation events were observed on 11 and 15 March. On both days, freshly nucleated particles grew to maximum sizes of about $60 \mathrm{~nm}$, over the course of about three hours in the early afternoons. Back trajectories show the air masses on both days were from the west/southwest (Fig. 5), and events were similar to those observed previously at SPL (Hallar et al., 2011). Particle concentrations on March 11 and 15 were higher than the previous two case studies, ranging from 1000 to $10000 \mathrm{~cm}^{-3}$ and 500 to $5000 \mathrm{~cm}^{-3}$ on 11 and 15 March, respectively, with the maximum concentrations during the NPF events. Concentrations of particles larger than $80 \mathrm{~nm}$ were $100-500 \mathrm{~cm}^{-3}$ for both days, and CCN concentrations ranged from 10 to $800 \mathrm{~cm}^{-3}$.

The top panels in Fig. 6a, b show the temporal evolution of particles' compositions for these two days. Biomass burning and sulfate-dominated particles were most prevalent on 11 March, with biomass burning particles dominating in the morning and evening, and sulfate-rich in the afternoon. Local wind directions showed slight shifts throughout the day, consistent with the change in dominating particles, with winds from the south/southwest in the morning and evening, and from the west in the afternoon. Composition-resolved aerosol size distributions were fairly similar across the different particle types. Composition on 15 March was more variable than that on 11 March, dominated in the morning by aged sea salt, changing to sulfate-dominant composition for the rest of day, with the presence of organics and biomass burning. Both days exhibit the "growing in" of sulfate from the morning into the early afternoon. Composition-resolved size distributions for 11 March, similar to the previous case studies, are similar for the different particle types, as seen in Fig. 7. 

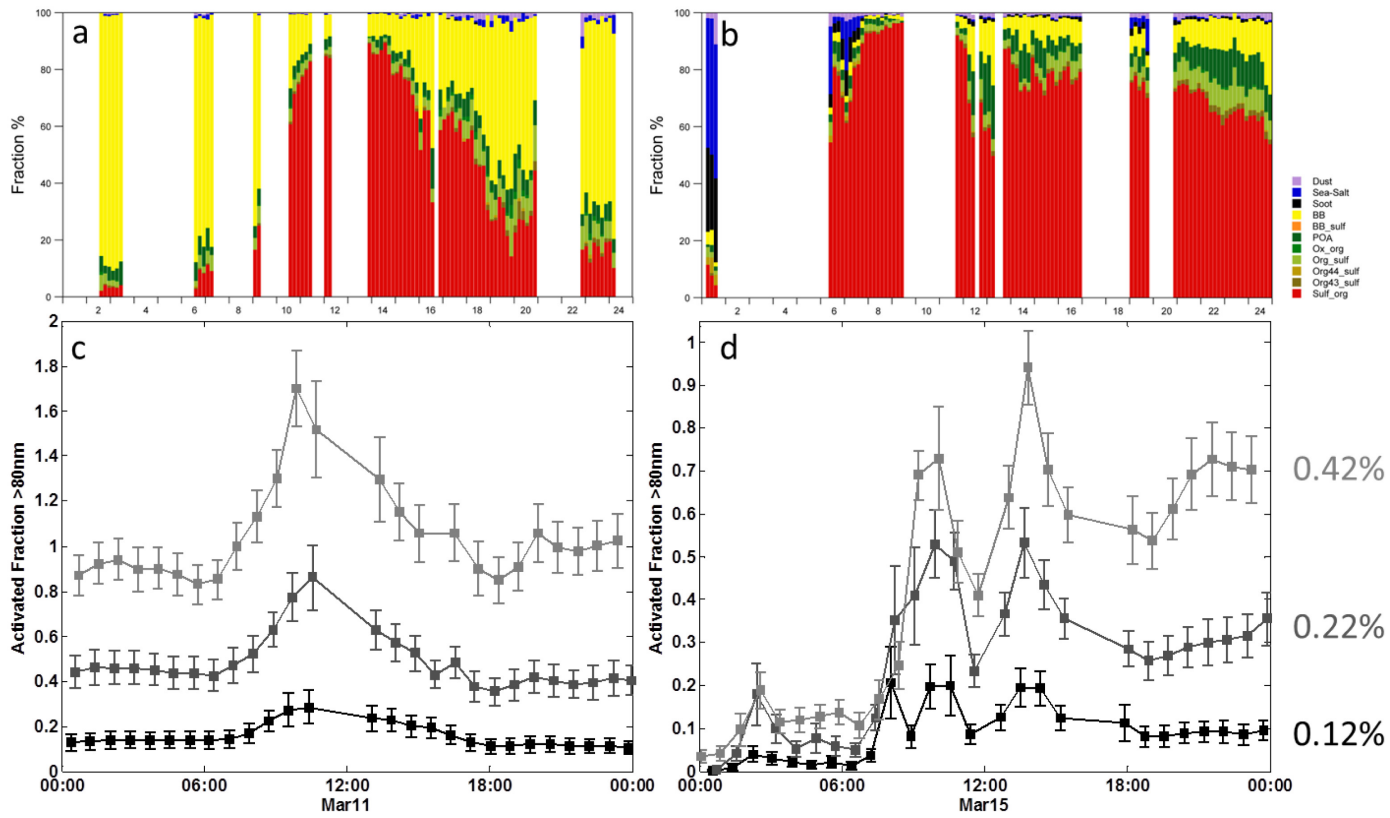

Fig. 6. Time evolution of composition throughout 11 March (a) and 15 March (b); Activated fraction of particles greater than $80 \mathrm{~nm}$ as a function of measured CCN supersaturation and time on 11 March (c) and 15 March (d). Note clusters and colors are the same for both days.

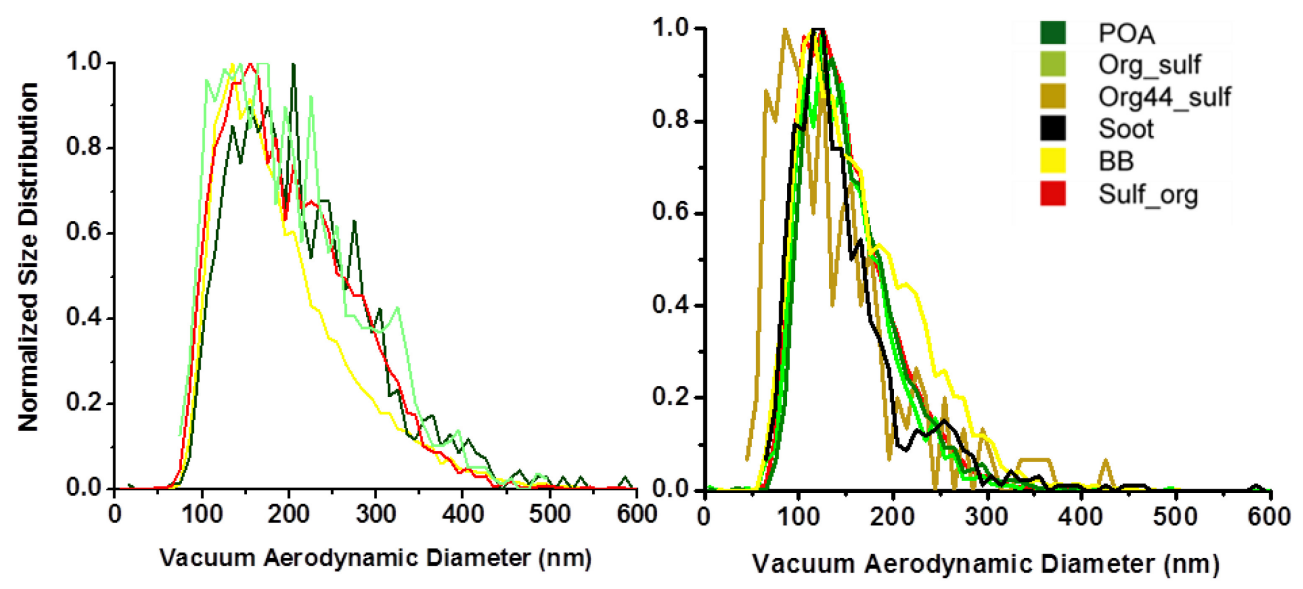

Fig. 7. Composition-resolved size distributions of aerosols sampled on 11 March (a) and 15 March (b). Note the colors are the same in both plots. Only the particle types that contributed measurably to the overall composition are shown.

On 15 March composition-resolved size distributions are also fairly similar across the different particle types, aside from the smaller particles in the Org44_sulf cluster. Density measurements for $100 \mathrm{~nm}$ particles exhibit a range from about $1.2 \mathrm{~g} \mathrm{~cm}^{-3}$ to $1.7 \mathrm{~g} \mathrm{~cm}^{-3}$, with peak densities of $1.5 \mathrm{~g} \mathrm{~cm}^{-3}$ and $1.4 \mathrm{~g} \mathrm{~cm}^{-3}$ for 11 and 15 March, respectively. These measurements corroborate that the particles were mainly composed of mixtures of sulfate and organic components, as well as biomass burning particles, especially on 11 March. Previous measurements of the density of biomass burning particles indicate a density of $1.3 \mathrm{~g} \mathrm{~cm}^{-3}$, which also contributes to the measured densities for the $100 \mathrm{~nm}$ particles (Vaden et al., 2011a).
Similar to the previous case studies, $\mathrm{CCN}$ activation for particles greater than $80 \mathrm{~nm}$ qualitatively follows the temporal evolution of the sulfate cluster for both days (Fig. 6c, d). Previous studies have suggested nucleated particles that are able to grow to sizes of at least $30 \mathrm{~nm}$ may contribute to $\mathrm{CCN}$ concentrations at high supersaturation conditions (Creamean et al., 2011; Dusek et al., 2010; Kerminen et al., 2005; Kuang et al., 2009; Kuwata et al., 2008; Laaksonen et al., 2005; Langley et al., 2010; Levin et al., 2012; Lihavainen et al., 2003; Lowenthal et al., 2002; Matsui et al., 2011; Riipinen et al., 2011; Sihto et al., 2011; Vakeva et al., 2002; Wiedensohler et al., 2009). Dusek et al. (2010) suggested that particles of size $40-50 \mathrm{~nm}$ are able to activate at higher supersaturation values 

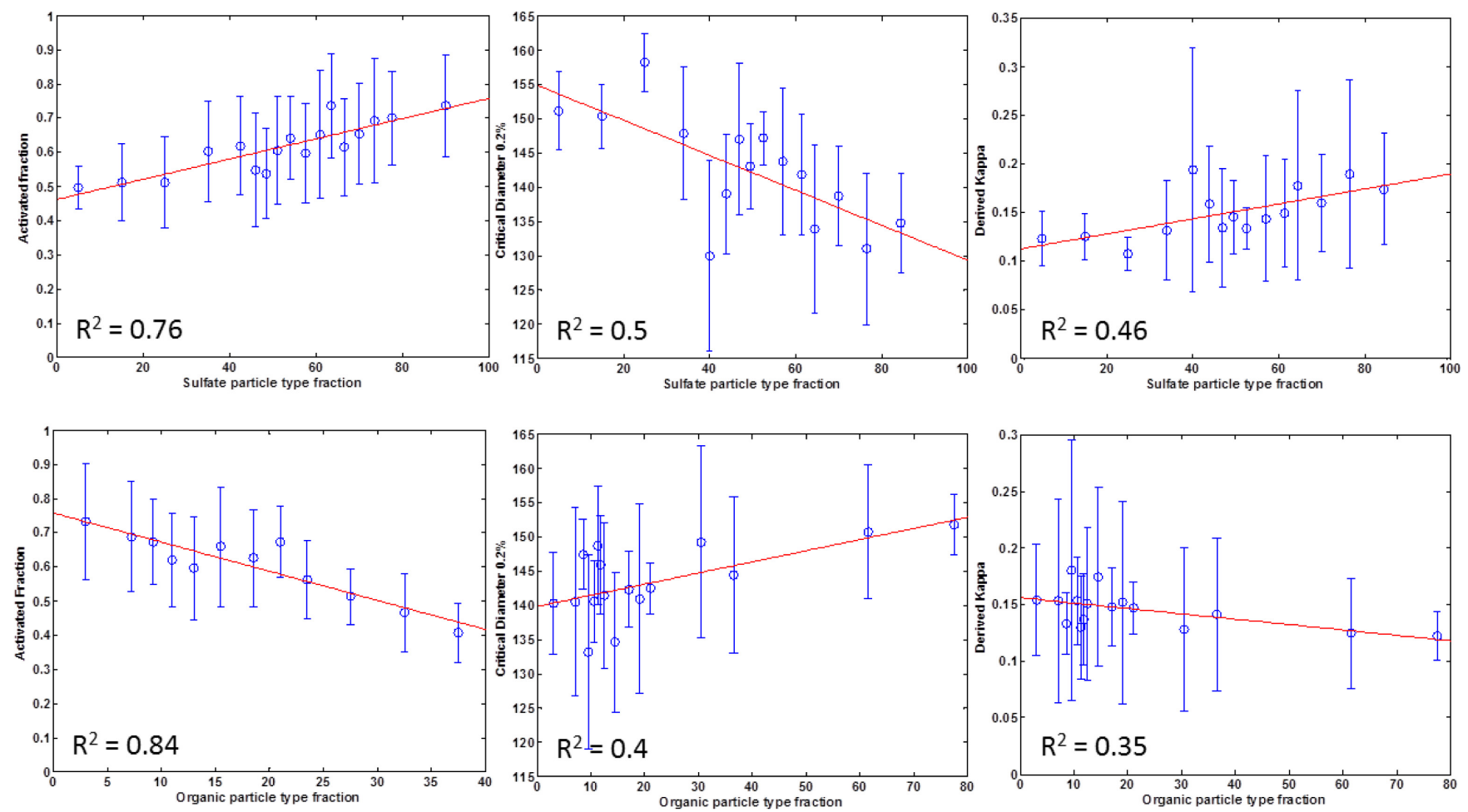

Fig. 8. Correlations between the fraction of sulfate-type particles (top panels) and organic-type particles (lower panels), as determined by SPLAT II, with the activated fraction of CCN (left panels), calculated critical diameter at $0.2 \%$ supersaturation (middle panels), and derived kappa parameter (right panels).

$(0.74 \%)$, and Lowenthal et al. (2002) suggested aerosol of sizes 30-40 nm observed at SPL may activate at supersaturation values greater than $0.5 \%$. Given that the lower detection limit of SPLAT II is $80 \mathrm{~nm}$, we hypothesize that particles of sizes smaller than $80 \mathrm{~nm}$ are able to act as $\mathrm{CCN}$ at the highest supersaturation conditions. Further, the slight increase in activated fraction at the end of both 11 and 15 March when biomass burning particles were increasing suggests the presence of hygroscopic material, such as sulfate, present in the particles smaller than $80 \mathrm{~nm}$.

\section{Derived hygroscopicity}

Köhler theory describes the composition and sizedependence of CCN activation (Köhler, 1936). A singleparameter representation of Köhler theory is described by a recently developed hygroscopicity parameter, kappa, which factors in aerosol composition information to represent the hygroscopic behavior of multi-component aerosol particles. Values of kappa vary between 0 for insoluble particles and 1.4 for highly soluble components (Petters and Kreidenweis, 2007).

The kappa parameter can be inferred from $\mathrm{CCN}$ and size distribution measurements by determining the critical diameter $D_{\text {crit }}$ at a given water vapor supersaturation. This is done by assuming fully internally mixed particles and integrating the number size distribution from its upper limit downward until the integrated number concentration is equal to the measured CCN concentration; it is assumed that all particles of size greater than the critical diameter will activate (Eq. 1). The diameter at which these two concentrations are equal is then taken as the critical diameter; the kappa parameter can then be calculated using Eq. (2).

$$
\begin{aligned}
& N_{\mathrm{CCN}, \text { measured }}(\mathrm{SS}, t)=\int_{D_{\text {crit }}(\mathrm{SS}, t)}^{\infty} N\left(\mathrm{D}_{p}, t\right) d \mathrm{D}_{p} \\
& \mathrm{SS}_{\text {crit }}=\left[\frac{4}{\kappa \mathrm{D}_{p}^{3}}\left(\frac{4 \sigma M_{\mathrm{w}}}{3 R T \rho_{\mathrm{w}}}\right)^{3 / 2}\right]^{1 / 2}
\end{aligned}
$$

In the above equation, $\kappa$ refers to the particle hygroscopicity kappa parameter, $\mathrm{D}_{p}$ the dry diameter, $M_{\mathrm{w}}$ the molar mass of water, $\sigma$ the surface tension of the solution, and $\rho_{\mathrm{w}}$ the density of water. Thus, the critical supersaturation $\left(\mathrm{SS}_{\text {crit }}\right)$ of a particle with known dry diameter and hygroscopicity can be determined, and the equation can be rearranged to determine the critical diameter necessary for $\mathrm{CCN}$ activation at a given supersaturation and hygroscopicity (Petters and Kreidenweis, 2007). Using this method to derive kappa from the SMPS and CCNC measurements and including all supersaturations studied, the campaign average 
kappa is $0.20( \pm 0.15)$. This value is consistent with an internal aerosol mixture of sulfate $(\kappa=0.61)$ and organics $(\kappa$ ranges $0-0.5$ ). While each particle is composed of a mixture of compounds and the aerosol contains particles of differing compositions and mixtures, representing this system as an internal mixture of sulfate and organics may not be a poor assumption. The campaign average of kappa is also within the ranges determined at similar sites, including 0.1-0.4 at a high-elevation site in Switzerland (Juranyi et al., 2010), 0.1-0.3 in the Alaskan Arctic (Moore et al., 2011; Lathem et al., 2013), 0.07-0.21 in northern Sweden (Kammermann et al., 2010), and 0.1-0.25 in California (Los Angeles basin, San Joaquin and Sacramento Valleys, eastern Pacific Ocean) (Moore et al., 2012). More recent field studies have found mean kappa values of 0.15 and 0.11 downwind of Sacramento, CA and Storm Peak Laboratory, respectively, with both sites reporting high organic-mass fractions (Hallar et al., 2013; Mei et al., 2013). Studies of continental aerosol reported a somewhat higher average kappa parameter of about 0.3 (Andreae and Rosenfeld, 2008), while a previous modeling study reported a global mean value of $0.27( \pm 0.21)$ for continental regions (Pringle et al., 2010). Kappa values determined for the detailed case study days of analysis range from $0.16-0.22$, with uncertainties ranging from $0.12-0.16$, similar to the overall campaign average. These results agree with previous studies and suggest that free tropospheric aerosol has a somewhat lower kappa value than continental aerosol. This likely reflects a different average aerosol composition between such locations. Correlations between the fractions of sulfate-type particles and organic-type particles with the activated fraction of $\mathrm{CCN}$, calculated critical diameter, and calculated kappa parameter are shown in Fig. 8. There exists a positive correlation of the activated fraction with the fraction of sulfate-type particles (and a negative correlation with organic-type particles). There is a similar correlation with the calculated critical diameter in that it decreases with increased sulfate particle types and increases with increased organic particle types, and a lesser correlation with the determined kappa parameters. We hypothesize this lesser correlation is largely due to the uncertainties in the kappa calculation related to the uncertainties propagated through the cube of the critical diameter and the square of the supersaturation in the kappa determination (Eq. 2). We also hypothesize that kinetic limitations of droplet growth may be contributing to the lower kappa (such as an organic coating on an inorganic particle) (Chuang et al., 1997). Furthermore, although compositional analysis shows that the majority of the aerosol at SPL contained sulfates, the kappa value of sulfates $(\sim 0.6)$ cannot be used to model the entire aerosol population $(\sim 0.2)$. A single kappa value is not a poor assumption for these measurements, although uncertainties and the range of kappa values derived needs to be taken into account in utilizing a single parameter in models, and detailed mixing state information is important in assessing the individual contributions of specific particle types to $\mathrm{CCN}$ activation.

\section{Conclusions}

In this study, $\mathrm{CCN}$ concentrations and associated single particle composition and size were measured at a high-elevation research site. Four case study days of detailed composition analysis were presented to compare $\mathrm{CCN}$ activation with single particle composition. On these days sulfate particle types dominated the aerosol composition by number; biomass burning, organic, soot, and sea salt particle types were also present. CCN activation largely followed the qualitative behavior of the sulfate particle types; biomass burning particle types, which increased likely due to local residential sources, also likely contained hygroscopic material that impacted CCN activation. Freshly nucleated particles also may contribute to $\mathrm{CCN}$ activation at higher supersaturation conditions. Derived kappa parameters corroborate that the aerosol was mainly mixtures of sulfate and organic components, and are within the range of previous reports of remote continental kappa values.

Acknowledgements. The authors would like to thank the Desert Research Institute's Storm Peak Laboratory staff, the Steamboat Springs ski area for logistic support. We furthermore thank the US Department of Energy's Office of Biological and Environmental Research (DOE-OBER) Atmospheric Radiation Measurement (ARM) StormVEx project, Atmospheric Research Program (ASR), and EMSL, a national scientific user facility sponsored by the DOE-OBER and located at Pacific Northwest National Laboratory for funding. DRI is an equal opportunity service provider and employer and a permittee of the Medicine-Bow Routt National Forest. The StormVEx campaign and all measurements included in this study were supported by the Office of Biological and Environmental Research of the U.S. Department of Energy as part of the Atmospheric Radiation Measurement Climate Research Facility. B. Friedman gratefully acknowledges support from the Department of Energy (DOE) Office of Science Graduate Fellowship Program (DOE SCGF). The DOE SCGF Program was made possible in part by the American Recovery and Reinvestment Act of 2009. The DOE SCGF program is administered by the Oak Ridge Institute for Science and Education for the DOE. ORISE is managed by Oak Ridge Associated Universities (ORAU) under DOE contract number DE-AC05-06OR23100. All opinions expressed in this paper are the author's and do not necessarily reflect the policies and views of DOE, ORAU, or ORISE.

Edited by: B. Ervens

\section{References}

Abbatt, J. P. D., Broekhuizen, K., and Kumar, P. P.: Cloud condensation nucleus activity of internally mixed ammonium sulfate/organic acid aerosol particles, Atmos. Environ., 39, 47674778, 2005.

Albrecht, B. A.: Aerosols, Cloud Microphysics, and Fractional Cloudiness, Science, 245, 1227-1230, 1989. 
Andreae, M. O. and Rosenfeld, D.: Aerosol-cloud-precipitation interactions. Part 1. The nature and sources of cloud-active aerosols, Earth-Sci. Rev., 89, 13-41, 2008.

Asa-Awuku, A., Moore, R. H., Nenes, A., Bahreini, R., Holloway, J. S., Brock, C. A., Middlebrook, A. M., Ryerson, T. B., Jimenez, J. L., DeCarlo, P. F., Hecobian, A., Weber, R. J., Stickel, R., Tanner, D. J., and Huey, L. G.: Airborne cloud condensation nuclei measurements during the 2006 Texas Air Quality Study, J. Geophys. Res., 116, D11201, doi:10.1029/2010JD014874, 2011.

Baustian, K. J., Cziczo, D. J., Wise, M. E., Pratt, K. A., Kulkarni, G., Hallar, A. G., and Tolbert, M. A.: Importance of aerosol composition, mixing state, and morphology for heterogeneous ice nucleation: A combined field and laboratory approach, J. Geophys. Res., 117, D06217, doi:10.1029/2011JD016784, 2012.

Bilde, M. and Svenningsson, B.: CCN activation of slightly soluble organics: the importance of small amounts of inorganic salt and particle phase, Tellus, 56B, 128-134, 2004.

Borys, R. D. and Wetzel, M. A.: Storm Peak Laboratory: A research, teaching, and service facility for the atmospheric sciences, B. Am. Meteor. Soc., 78, 2115-2123, 1997.

Broekhuizen, K., Kumar, P. P., and Abbatt, J. P. D.: Partially soluble organics as cloud condensation nuclei: Role of trace soluble and surface active species, Geophys. Res. Lett., 31, L01107, doi:10.1029/2003GL018203, 2004.

Chang, R. Y.-W., Liu, P. S. K., Leaitch, W. R., and Abbatt, J. P. D.: Comparison between measured and predicted CCN concentrations at Egbert, Ontario: Focus on the organic aerosol fraction at a semi-rural site, Atmos. Environ., 41, 8172-8182, 2007.

Chuang, P. Y., Charlson, R. J., and Seinfeld, J. H.: Kinetic Limitations on Droplet Formation in Clouds, Nature, 390, 594-596. 1997.

Creamean, J. M., Ault, A. P., Ten Hoeve, J. E., Jacobson, M. Z., Roberts, G. C., and Prather, K. A.: Measurements of aerosol chemistry during new particle formation events at a remote rural mountain site, Environ. Sci. Technol., 45, 8208-8216, 2011.

Cubison, M. J., Ervens, B., Feingold, G., Docherty, K. S., Ulbrich, I. M., Shields, L., Prather, K., Hering, S., and Jimenez, J. L.: The influence of chemical composition and mixing state of Los Angeles urban aerosol on CCN number and cloud properties, Atmos. Chem. Phys., 8, 5649-5667, doi:10.5194/acp-8-5649-2008, 2008.

Dusek, U., Frank, G. P., Hildebrandt, L., Curtius, J., Schneider, J., Walter, S., Chang, D., Drewnick, F., Hings, S., Jung, D., Borrmann, S., Andreae, M. O.: Size matters more than chemistry for cloud-nucleating ability of aerosol particles, Science, 312, 1375, doi:10.1126/science.1125261, 2006.

Dusek, U., Frank, G. P., Curtius, J., Drewnick, F., Schneider, J., Kurten, A., Rose, D., Andreae, M. O., Borrmann, S., Pöschl, U.: Enhanced organic mass fraction and decreased hygroscopicity of cloud condensation nuclei $(\mathrm{CCN})$ during new particle formation events, Geophys. Res. Lett., 37, L03804, doi:10.1029/2009GL040930, 2010.

Ervens, B., Cubison, M. J., Andrews, E., Feingold, G., Ogren, J. A., Jimenez, J. L., Quinn, P. K., Bates, T. S., Wang, J., Zhang, Q., Coe, H., Flynn, M., and Allan, J. D.: CCN predictions using simplified assumptions of organic aerosol composition and mixing state: a synthesis from six different locations, Atmos. Chem. Phys., 10, 4795-4807, doi:10.5194/acp-10-4795-2010, 2010.
Forster, P., Ramaswamy, V., Artaxo, P., Berntsen, T., Betts, R., Fahey, D. W. Haywood, J., Lean, J., Lowe, D. C., Myhre, G., Nganga, J., Prinn, R., Raga, G., Schulz, M., and Van Dorland, R.: Changes in Atmospheric Constituents and in Radiative Forcing. In: Climate Change 2007: The Physical Science Basis. Contribution of Working Group I to the Fourth Assessment Report of the Intergovernmental Panel on Climate Change, edited by: Solomon, S., Qin, D., Manning, M., Chen, Z., Marquis, M., Averyt, K. B., Tignor, M., and Miller, H. L., Cambridge University Press, Cambridge, United Kingdom and New York, NY, USA, 2007.

Furutani, H., Dall'osto, M., Roberts, G. C., and Prather, K. A.: Assessment of the relative importance of atmospheric aging on $\mathrm{CCN}$ activity derived from field observations, Atmos. Environ., 42, 3130-3142, 2008.

Hallar, A. G., Lowenthal, D. H., Chirokova, G., Borys, R. D., and Wiedinmyer, C.: Persistent daily new particle formation at a mountain-top location, Atmos. Environ., 45, 4111-4115, 2011.

Hallar, A. G., Lowenthal, D. H., Clegg, S. L., Samburova, V., Taylor, N., Mazzoleni, L. R., Zielinska, B. K., Kristensen, T. B., Chirokova, G., McCubbin, I. B., Dodson, C., and Collins, D.: Chemical and hygroscopic properties of aerosol organics at Storm Peak Laboratory, J. Geophys. Res., 118, 1-13, doi:10.1002/jgrd.50373, 2013.

Juranyi, Z., Gysel, M., Weingartner, E., DeCarlo, P. F., Kammermann, L., and Baltensperger, U.: Measured and modelled cloud condensation nuclei number concentration at the high alpine site Jungfraujoch, Atmos. Chem. Phys., 10, 7891-7906, doi:10.5194/acp-10-7891-2010, 2010.

Kammermann, L., Gysel, M., Weingartner, E., Herich, H., Cziczo, D. J., Holst, T., Svenningsson, B., Arneth, A., and Baltensperger, U.: Subarctic atmospheric aerosol composition: 3. Measured and modeled properties of cloud condensation nuclei,J. Geophys. Res., 115, D04202, doi:10.1029/2009JD012447 2010.

Kerminen, V.-M., Lihavainen, H., Komppula, M., Viisanen, Y., and Kulmala, M.: Direct observational evidence linking atmospheric aerosol formation and cloud droplet activation, Geophys. Res. Lett., 32, L14803, doi:10.1029/2005GL023130, 2005.

Köhler, H.: The nucleus in and the growth of hygroscopic droplets, T. Faraday. Soc., 43, 1152-1161, 1936.

Kuang, C., McMurry, P. H., and McCormick, A. V.: Determination of cloud condensation nuclei production from measured new particle formation events, Geophys. Res. Lett., 36, L09822, doi:10.1029/2009GL037584, 2009.

Kumar, P. P., Broekhuizen, K., and Abbatt, J. P. D.: Organic acids as cloud condensation nuclei: Laboratory studies of highly soluble and insoluble species, Atmos. Chem. Phys., 3, 509-520, doi:10.5194/acp-3-509-2003, 2003.

Kuwata, M., Kondo, Y., Miyazaki, Y., Komazaki, Y., Kim, J. H., Yum, S. S., Tanimoto, H., and Matsueda, H.: Cloud condensation nuclei activity at Jeju Island, Korea in spring 2005, Atmos. Chem. Phys., 8, 2933-2948, doi:10.5194/acp-8-2933-2008, 2008.

Laaksonen, A., Hamed, A., Joutsensaari, J., Hiltunen, L., Cavalli, F., Junkermann, W., Asmi, A., Fuzzi, S., and Facchini, M. C.: Cloud condensation nucleus production from nucleation events at a highly polluted region, Geophys. Res. Lett., 32, L06812, doi:10.1029/2004GL022092, 2005. 
Lance, S., Medina, J., Smith, N., and Nenes, A.: Mapping the operation of the DMT continuous flow CCN counter, Aerosol Sci. Technol., 40, 242-254, doi:10.1080/02786820500543290, 2006.

Lance, S., Nenes, A., Mazzoleni, C., Dubey, M. K., Gates, H., Varutbangkul, V., Rissman, T. A., Murphy, S. M., Sorooshian, A., Flagan, R., Seinfeld, J. H., Feingold, G., and Jonsson, H. H.: Cloud condensation nuclei activity, closure, and droplet growth kinetics of Houston aerosol during the Gulf of Mexico Atmospheric Composition and Climate Study (GoMACCS), J. Geophys. Res., 114, D00F15, doi10.1029/2008JD011699, 2009.

Langley, L., Leaitch, W. R., Lohmann, U., Shantz, N. C., and Worsnop, D. R.: Contributions from DMS and ship emissions to $\mathrm{CCN}$ observed over the summertime North Pacific, Atmos. Chem. Phys., 10, 1287-1314, doi:10.5194/acp-10-1287-2010, 2010.

Lathem, T. L., Beyersdorf, A. J., Thornhill, K. L., Winstead, E. L., Cubison, M. J., Hecobian, A., Jimenez, J. L., Weber, R. J., Anderson, B. E., and Nenes, A.: Analysis of CCN activity of Arctic aerosol and Canadian biomass burning during summer 2008, Atmos. Chem. Phys., 13, 2735-2756, doi:10.5194/acp-13-27352013, 2013.

Lihavainen, H., Kerminen, V.-M., Komppula, M., Hatakka, J., Aaltonen, V., Kumala, M., and Viisanen, Y.: Production of "potential" cloud condensation nuclei associated with atmospheric newparticle formation in northern Finland, J. Geophys. Res., 108, 4782, doi:10.1029/2003JD003887, 2003.

Lowenthal, D. H., Borys, R. D., and Wetzel, M. A.: Aerosol distributions and cloud interactions at a mountaintop lab, J. Geophys. Res., 107, AAC 1-1-PAU 8-14, doi:10.1029/2001JD002046, 2002.

Martin, M., Chang, R.Y.-W., Sierau, B., Sjogren, S., Swietlicki, E., Abbatt, J. P. D., Leck, C., and Lohmann, U.: Cloud condensation nuclei closure study on summer arctic aerosol, Atmos. Chem. Phys., 11, 11335-11350, doi:10.5194/acp-11-11335-2011, 2011.

Matrosov, S. Y., Mace, G. G., Marchand, R., Shupe, M. D., Hallar, A. G., and McCubbin, I. B.: Influence of Ice Hydrometeor Habits on Scanning Polarimertic Cloud Radar Measurements, J. Atmos. Ocean. Technol., 29, 989-1008, 2012.

Matsui, H., Koike, M., Kondo, Y., Takegawa, N., Wiedensohler, A., Fast, J. D., and Zaveri, R. A.: Impact of new particle formation on the concentrations of aerosols and cloud condensation nuclei around Beijing, J. Geophys. Res., 116, D19208, doi:10.1029/2011JD016025, 2011.

McFiggans, G., Artaxo, P., Baltensperger, U., Coe, H., Facchini, M. C., Feingold, G., Fuzzi, S., Gysel, M., Laaksonen, A., Lohmann, U., Mentel, T. F., Murphy, D. M., O’Dowd, C. D., Snider, J. R., and Weingartner, E.: The effect of physical and chemical aerosol properties on warm cloud droplet activation, Atmos. Chem. Phys., 6, 2593-2649, doi:10.5194/acp-6-2593-2006, 2006.

Mei, F., Setyan, A., Zhang, Q., and Wang, J.: CCN activity of organic aerosols observed downwind of urban emissions during CARES, Atmos. Chem. Phys. Discuss., 13, 9355-9399, doi:10.5194/acpd-13-9355-2013, 2013.

Moore, R. H., Bahreini, R., Brock, C. A., Froyd, K. D., Cozic, J., Holloway, J. S., Middlebrook, A. M., Murphy, D. M., and Nenes, A.: Hygroscopicity and composition of Alaskan Arctic CCN during April 2008, Atmos. Chem. Phys., 11, 11807-11825, doi:10.5194/acpd-11-9355-2011, 2011.
Moore, R. H., Cerully, K., Bahreini, R., Brock, C. A., Middlebrook, A. M., and Nenes, A.: Hygroscopicity and composition of California CCN during summer 2010, J. Geophys. Res., 117, D00V12, doi:10.1029/2011JD017352, 2012.

Murphy, D. M., Cziczo, D. J., Froyd, K. D., Hudson, P. K., Matthew, B. M., Middlebrook, A. M., Peltier, R. E., Sullivan, A., Thomson, D. S., and Weber, R. J.: Single-particle mass spectrometry of tropospheric aerosol particles, J. Geophys. Res., 111, D23S32, doi:10.1029/2006JD007340, 2006.

Petters, M. D. and Kreidenweis, S. M.: A single parameter representation of hygroscopic growth and cloud condensation nucleus activity, Atmos. Chem. Phys., 7, 1961-1971, doi:10.5194/acpd7-1961-2007, 2007.

Pringle, K. J., Tost, H., Pozzer, A., Pöschl, U., and Lelieveld, J.: Global distribution of the effective aerosol hygroscopicity parameter for CCN activation, Atmos. Chem. Phys., 10, 52415255, doi:10.5194/acp-10-5241-2010, 2010.

Raymond, T. and Pandis, S. N.: Cloud activation of singlecomponent organic aerosol particles, J. Geophys. Res., 107, 4787, doi:10.1029/2002JD002159, 2002.

Raymond, T. and Pandis, S. N.: Formation of cloud droplets by multicomponent organic particles, J. Geophys. Res., 108, doi:10.1029/2003JD003503, 4469, 2003.

Richardson, M. S., DeMott, P. J., Kreidenweis, S. M., Cziczo, D. J., Dunlea, E. J., Jimenez, J. L., Thomson, D. S., Ashbaugh, L. L., Borys, R. D., Westphal, D. L., Casuccio, G. S., and Lersch, T. L.: Measurements of heterogeneous ice nuclei in the western United States in springtime and their relation to aerosol characteristics, J. Geophys. Res., 112, D02209, doi:10.1029/2006JD007500, 2007.

Riipinen, I., Pierce, J. R., Yli-Juuti, T., Nieminen, T., Hakkinen, S., Ehn, M., Junninen, H., Lehtipalo, K., Petaja, T., Slowik, J., Chang, R., Shantz, N. C., Abbatt, J., Leaitch, W. R., Kerminen, V.-M., Worsnop, D. R., Pandis, S. N., Donahue, N. M., and Kulmala, M.: Organic condensation: a vital link connecting aerosol formation to cloud condensation nuclei $(\mathrm{CCN})$ concentrations, Atmos. Chem. Phys., 11, 3865-3878, doi:10.5194/acp-11-38652011, 2011.

Roberts, G. C. and Nenes, A.: A continuous-flow streamwise thermal-gradient $\mathrm{CCN}$ chamber for atmospheric measurements, Aerosol Sci. Tech., 39, 206-221, 2005.

Roberts, G. C., Day, D. A., Russell, L. M., Dunlea, E. J., Jimenez, J. L., Tomlinson, J. M., Collins, D. R., Shinozuka, Y., and Clarke, A. D.: Characterization of particle cloud droplet activity and composition in the free troposphere and the boundary layer during INTEX-B, Atmos. Chem. Phys., 10, 6627-6644, doi:10.5194/acp-10-6627-2010, 2010.

Sihto, S.-L., Mikkilä, J., Vanhanen, J., Ehn, M., Liao, L., Lehtipalo, K., Aalto, P. P., Duplissy, J., Petäjä, T., Kerminen, V.-M., Boy, M., and Kulmala, M.: Seasonal variation of CCN concentrations and aerosol activation properties in boreal forest, Atmos. Chem. Phys., 11, 13269-13285, doi:10.5194/acp-11-13269-2011, 2011.

Twomey, S.: The influence of pollution on the shortwave albedo of clouds, J. Atmos. Sci., 34, 1149-1152, 1977.

Vaden, T., Imre, D., Beranek, J., and Zelenyuk, A.: Extending the Capabilities of Single Particle Mass Spectrometry: II. Measurements of Aerosol Particle Density without DMA, Aerosol Sci. Technol., 45, 125-135, 2011a. 
Vaden, T. D., Imre, D., Beranek, J., and Zelenyuk, A.: Extending the Capabilities of Single Particle Mass Spectrometry: I. Measurements of Aerosol Number Concentration, Size Distribution, and Asphericity, Aerosol Sci. Technol., 45, 113-124, $2011 \mathrm{~b}$.

Vakeva, M., Hameri, K., and Aalto, P. P.: Hygroscopicity properties of nucleation mode and Aitken mode particles during nucleation bursts and in background air on the west coast of Ireland, J. Geophys. Res., 107, 8104, doi:10.1029/2000JD000176, 2002.

Wang, J., Lee, Y.-N., Daum, P. H., Jayne, J., and Alexander, M. L.: Effects of aerosol organics on cloud condensation nucleus (CCN) concentration and first indirect aerosol effect, Atmos. Chem. Phys., 8, 6325-6339, doi:10.5194/acp-8-6325-2008, 2008.

Wiedensohler, A., Cheng, Y. F., Nowak, A., Wehner, B., Achtert, P., Berghof, M., Birmili, W., Wu, Z. J., Hu, M., Zhu, T., Takegawa, N., Kita, K., Kondo, Y., Lou, S. R., Hofzumahaus, A., Holland, F., Wahner, A., Gunthe, S. S., Rose, D., Su, H., and Pöschl, U.: Rapid aerosol particle growth and increase of cloud condensation nucleus activity by secondary aerosol formation and condensation: A case study for regional air pollution in northeastern China, J. Geophys. Res., 114, D00G08, doi:10.1029/2008JD010884, 2009.

Wong, J. P. S., Lee, A. K. Y., Slowik, J. G., Cziczo, D. J., Leaitch, W. R., Macdonald, A., Abbatt, J. P. D.:Oxidation of ambient biogenic secondary organic aerosol by hydroxyl radicals: effects on cloud condensation nuclei activity, Geophys. Res. Lett., 38, L22805, doi:10.1029/2011GL049351, 2011.

Zaveri, R. A., Shaw, W. J., Cziczo, D. J., Schmid, B., Ferrare, R. A., Alexander, M. L., Alexandrov, M., Alvarez, R. J., Arnott, W. P., Atkinson, D. B., Baidar, S., Banta, R. M., Barnard, J. C., Beranek, J., Berg, L. K., Brechtel, F., Brewer, W. A., Cahill, J. F., Cairns, B., Cappa, C. D., Chand, D., China, S., Comstock, J. M., Dubey, M. K., Easter, R. C., Erickson, M. H., Fast, J. D., Floerchinger, C., Flowers, B. A., Fortner, E., Gaffney, J. S., Gilles, M. K., Gorkowski, K., Gustafson, W. I., Gyawali, M., Hair, J., Hardesty, R. M., Harworth, J. W., Herndon, S., Hiranuma, N., Hostetler, C., Hubbe, J. M., Jayne, J. T., Jeong, H., Jobson, B. T., Kassianov, E. I., Kleinman, L. I., Kluzek, C., Knighton, B., Kolesar, K. R., Kuang, C., Kubatova, A., Langford, A. O., Laskin, A., Laulainen, N., Marchbanks, R. D., Mazzoleni, C., Mei, F., Moffet, R. C., Nelson, D., Obland, M. D., Oetjen, H., Onasch, T. B., Ortega, I., Ottaviani, M., Pekour, M., Prather, K. A., Radney, J. G., Rogers, R. R., Sandberg, S. P., Sedlacek, A., Senff, C. J., Senum, G., Setyan, A., Shilling, J. E., Shrivastava, M., Song, C., Springston, S. R., Subramanian, R., Suski, K., Tomlinson, J., Volkamer, R., Wallace, H. W., Wang, J., Weickmann, A. M., Worsnop, D. R., Yu, X. Y., Zelenyuk, A. and Zhang, Q. (2012). Overview of the 2010 Carbonaceous Aerosols and Radiative Effects Study (CARES), Atmos. Chem. Phys., 12, 76477687, doi:10.5194/acp-12-7647-2012, 2012.
Zelenyuk, A. and Imre, D.: Beyond single particle mass spectrometry: Multidimensional characterization of individual aerosol particles, Int. Rev. Phys. Chem., 28, 309-358, doi:10.1080/01442350903037458, 2009.

Zelenyuk, A., Imre, D., Cai, Y., Mueller, K., Han, Y., Imrich, P.: SpectraMiner, an Interactive Data Mining and Visualization Software for Single Particle Mass Spectroscopy: A Laboratory Test Case, Int. J. Mass Spectrom., 258, 58-73, 2006.

Zelenyuk, A., Yang, J., Choi, E., and Imre, D.: SPLAT II: An Aircraft Compatible, Ultra-Sensitive, High Precision Instrument for In-Situ Characterization of the Size and Composition of Fine and Ultrafine Particles, Aerosol Sci. Technol., 43, 411-424, 2009.

Zelenyuk, A., Ezell, M. J., Perraud, V., Johnson, S. N., Bruns, E. A., Yu, Y., Imre, D., Alexander, M. L., and Finlayson-Pitts, B. J.: Characterization of Organic Coatings on Hygroscopic Salt Particles and their Atmospheric Impacts, Atmos. Environ., 44, 1209$1218,2010$. 